\title{
Rancang Bangun Alat Ukur Kelembaban Tanah Berbasis Arduino Uno
}

\author{
I Gusti Eka Darmawan ${ }^{1}$, Erry Yadie $^{2}$, Hari Subagyo ${ }^{3}$ \\ 1,2,3 Jurusan Teknik Elektro, Politeknik Negeri Samarinda \\ Jl. Dr. Ciptomangunkusumo, Kampus Gunung Panjang, Samarinda, 75121 \\ erryyadie@polnes.ac.id
}

\begin{abstract}
Abstrak - Alat ukur kelembaban tanah ini menggunakan Arduino Uno dan soil moisture sensor YL 69. Alat ukur ini dapat dipergunakan untuk manajemen sumber daya air, peringatan awal kekeringan, penjadwalan irigasi, dan perkiraan cuaca. Berdasarkan hasil pengujian dan beberapa proses kalibrasi, alat hasil rancang bangun dapat memberikan 3 informasi yaitu ADC (Analog to Digital Converter), persentase kelembaban, dan kategori kondisi tanah yang diukur. Pengkategorian 5 kondisi tanah terbagi sebagai berikut (sangat kering, kering, normal, basah, dan sangat basah). Berdasarkan media pengacu atau pembanding, alat hasil rancang bangun ini memiliki selisih pengukuran persentase kelembaban kurang lebih 1,7 \% dengan alat ukur Soil Tester Takamura Model DM 05.
\end{abstract}

Kata Kunci : Arduino Uno, soil moisture YL 69, Soil Tester DM 5.

\section{Pendahuluan}

Tanah adalah lapisan permukaan bumi yang secara fisik berfungsi sebagai tempat tumbuh dan berkembangnya perakaran penompang penompang tegak tumbuhnya tanaman dan menyuplai kebutuhan air. Secara kimiawi berfungsi sebagai gudang dan penyuplai hara atau nutrisi ( senyawa organik dan anorganik serta unsur - unsur esensial ). Secara biologis tanah berfungsi sebagai habitat biota yang berpartisipasi aktif dalam penyediaan hara dan zat - zat aditif bagi tanaman. Fungsi ketiganya secara integral mampu menunjang produktivitas tanah untuk menghasilkan biomass dan produksi baik tanaman pangan, obat - obatan, industri, perkebunan, maupun kehutanan.

Faktor kelembaban sangat penting bagi tanah untuk proses pelapukan mineral dan bahan organik tanah. Akan tetapi jika terlalu lembab maka pergerakaan udara di dalam tanah akan terbatasi menghalangi akar tanaman mendapatkan oksigen sehingga menyebabkan kematian. Untuk mengetahui informasi kelembaban tanah adalah dengan mengukur langsung. Untuk memudahkan dalam pemantauan fluktuasi dalam waktu yang cepat, dibuatlah alat ukur kelembaban tanah berbasis Arduino Uno.

Perkembangan teknologi sekarang ini sudah mengalami kemajuan yang sangat pesat. Alat - alat dengan teknologi canggih telah banyak ditemukan seiring dengan kebutuhan manusia yang semakin kompleks. Khususnya dibidang elektronika, segala aspek kehidupan manusia saat ini dan mendatang tidak akan lepas dari perkembangan teknologi ini.Informasi kelembaban tanah juga dapat dipergunakan untuk manajemen sumber daya air, peringatan awal kekeringan, penjadwalan irigasi, dan perkiraan cuaca. Selain itu, informasi tentang kondisi kelembaban tanah dan distribusinya sangat penting agar pemerintah dapat merencanakan dan mengelola produksi tanaman dengan baik.

Submitted: 30/01/2020; Revised: 30/01/2020;

Accepted: 30/06/2020; Online first: 30/06/2020

http://dx.doi.org/10.46964/poligrid.v1i1.215

\section{LANDASAN TEORI}

\section{A. Kelembaban Tanah}

Kelembaban tanah adalah jumlah air yang ditahan di dalam tanah setelah kelebihan air dialirkan, apabila tanah memiliki kadar air yang tinggi maka kelebihan air tanah dikurangi melalui evaporasi.

Kelembaban tanah merupakan pernyataan jumlah air pada pori-pori tanah. Kelembaban tanah sangat dinamis. Hal ini disebabkan oleh penguapan melalui permukaan tanah, transpirasi dan perkolasi.

Kelembaban tanah memiliki peranan penting bagi pemerintah untuk mengetahui informasi seperti potensi aliran permukaan dan pengendali banjir, kegagalan erosi tanah dan kemiringan lereng, manajemen sumber daya air, geoteknik, dan kualitas air [1].

\section{B. Kadar Air Tanah}

Faktor yang mempengaruhi kadar air tanah yaitu bahan organik tanah mempunyai pori-pori yang jauh lebih banyak daripada partikel mineral tanah yang berarti luas permukaan penyerapan juga lebih banyak sehingga makin tinggi kadar bahan organic tanah makin tinggi kadar dan ketersediaan air tanah. Faktor lainnya yang mempengaruhi kadar air tanah adalah tekstur tanah, dengan adanya perbedaan jenis tekstur tanah dapat menggambarkan tingkat kemampuan tanah untuk mengikat air, contohnya tanah yang bertekstur liat lebih mampu mengikat air dalam jumlah banyak dibandingkan tanah yang bertekstur pasir, sedangkan tanah bertekstur pasir lebih mampu mengikat air daripada tanah bertekstur debu [2].

\section{Mikrokontroller}

Mikrokontroller adalah sebuah komputer kecil ("special purpose computers") di dalam satu IC yang berisi CPU, memori, timer, saluran komunikasi serial dan paralel, Port input/output, ADC. Mikrokontroller digunakan untuk suatu tugas dan menjalankan suatu program [1].

Mikrokontroller ini adalah suatu alat elektronika digital yang mempunyai masukan dan keluaran serta kendali dengan program yang bisa ditulis an dihapus dengan cara khusus. Tidak seperti sistem komputer, yang mampu menangani berbagai macam program aplikasi (misalnya pengolah kata, pengolah angka dan lain sebagainya), mikrokontroller hanya bisa digunakan untuk suatu aplikasi tertentu saja (hanya satu program saja yang bisa disimpan) [3]. 


\section{Arduino Uno}

Arduino merupakan papan rangkaian sistem minimum mikrokontroller yang memang dirancang untuk bisa digunakan dengan mudah oleh para seniman dan desainer (yang memang bukan orang teknik). Dengan demikian, tanpa mengetahui bahasa pemrograman, Arduino bisa digunakan untuk menghasilkan karya yang canggih, pada Gambar 1 adalah salah satu contoh bentuk fisik dari Arduino.

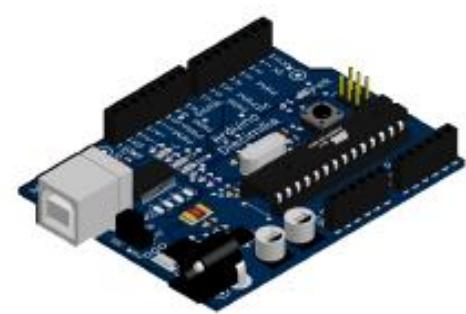

Gambar 1. Arduino Uno [4]

\section{E. Sensor Kelembaban Tanah (YL - 69)}

Sensor kelembaban tanah jenis YL - 69 ini merupakan sensor yang banyak digunakan untuk otomatisasi system penyiraman tanaman. Sensor YL - 69 ini merupakan probe yang memiliki dua konduktor yang berfungsi untuk membaca kelembaban tanah dalam bentuk resistansi. Hubungan Panjang probe dengan nilai tegangan $\mathrm{ADC}$ maupun nilai resistivitas diperoleh bahwa semakin dalam probe sensor YL - 69 menancap ke tanah maka nilai resistansi akan semakin menurun hal ini mewakili kondisi kelembaban tanah, semakin banyak kontak antara air atau tanah dengan probe sensor maka semakin sensitive sensor tersebut dalam membaca kondisi kelembaban. Seperti pada Gambar 2 adalah bentuk fisik dari sensor kelembaban tanah (YL-69) [5]

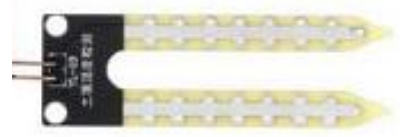

Gambar 2. Sensor kelembaban tanah (YL - 69) [5]

\section{F. I2C (Inter-Intergrated Circuit)}

I2C merupakan singkatan dari Inter-Intergrated Circuit, yang disebut dengan $I$-squared-C atau $I$-two- $C$. I2C merupakan protokol yang digunakan pada multi-master serial computer bus yang diciptakan oleh Philips yang digunakan untuk saling berkomunikasi dengan perangkat low-speed lainnya yang diaplikasikan pada motherboard, embedded system atau cellphone. Jalur I2C bus hanya merupakan 2 jalur yang disebut dengan SDA line dan SCL line, dimana SCL line merupakan jalur untuk clock dan SDA line merupakan jalur untuk data. Semua peralatan yang akan digunakan dihubungkan seluruhnya pada jalur SDA line dan SCL line dari I2C bus tersebut. Seperti dalam SPI dan juga akan berbeda diantara berbagai chip I2C. Implementasi penuh I2C memungkinkan beberapa perangkat untuk berbagi satu bus, tetapi kemampuan ini mungkin tetap tidak terpakai [6]. Pada Gambar 3 adalah salah satu contoh bentuk fisik dari I2C.

Submitted: 30/01/2020; Revised: 30/01/2020;

Accepted: 30/06/2020; Online first: 30/06/2020

http://dx.doi.org/10.46964/poligrid.v1i1.215

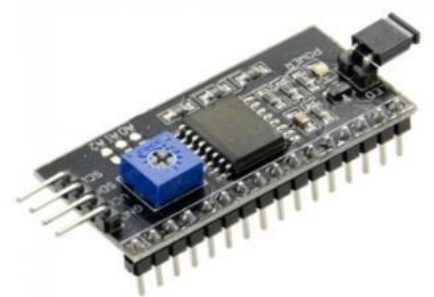

Gambar 3. I2C (Inter-Integrated Circuit) [6]

\section{G. Alat Pembanding Data}

Alat pembanding data sangatlah diperlukan dalam penelitian sebagai media perbandingan dan pengujian data yang diperoleh dari rancang bangun alat ukur kelembaban tanah berbasis Arduino Uno. Alat pembanding yang digunakan yaitu Takemura DM 5 Soil pH Meter And Humidity, seperti yang ditunjukan pada Gambar 4.

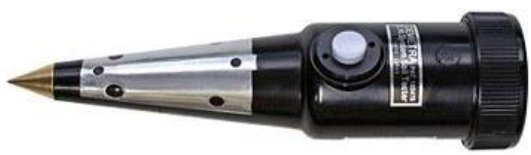

Gambar 4. Takemura DM 5 Soil pH Meter And Humidity [7]

\section{Metodologi PERANCANGAN}

\section{A. Gambaran Umum Sistem}

Dalam pembuatan alat ukur kelembaban tanah berbasis Arduino Uno, melalui beberapa tahap-tahap seperti perancangan, perakitan alat, pengambilan data, kalibrasi alat, perbandingan, dan terakhir yaitu uji coba alat. Alat ukur kelembaban tanah berbasis Arduino Uno meliputi Arduino Uno, bread board, tampilan LCD, dan soil moisture sensor YL - 69. Dapat dilihat pada Gambar 5 diagram blok sistem.

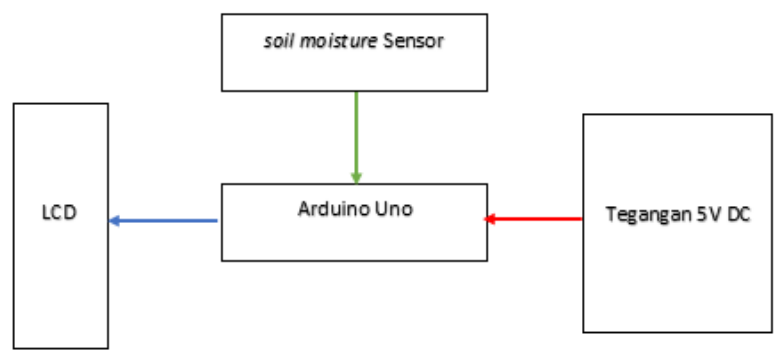

Keterangan :

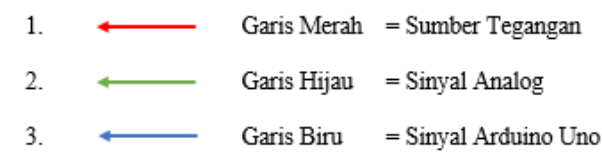

Gambar 5. Diagram blok sistem 


\section{B. Desain Perancangan}

Pada pembuatan alat ini, berikut beberapa perancangan yang dibangun dalam proses rancang bangun alat ukur kelembaban tanah berbasis Arduino Uno ini yang diantaranya adalah :

1. Perancangan rangkaian Arduino Uno ke LCD.

2. Perancangan rangkaian Arduino Uno ke soil moisture sensor YL 69.

3. Perancangan box / wadah.

\section{Perancangan Rangkaian Arduino Uno ke LCD}

Pada rancang bangun alat ukur kelembaban tanah berbasis Arduino Uno ini untuk memudahkan dalam pembacaan hasil pengukuran kelembaban, maka diperlukan LCD sebagai komponen yang menampilkan hasil pengukuran yaitu ADC, Persentase kelembaban tanah, dan 5 kondisi Tanah yaitu Kering Sekali, Kering, Normal, Basah, dan Basah Sekali. Penggunaan LCD langsung pada Arduino Uno sangatlah banyak memerlukan line komunikasi, dengan menggunakan PCF8574A I2C-Bus akan mempersedikit line komunikasi menuju Arduino Uno. Dapat dilihat pada Gambar 6 line diagram koneksi line komunikasi PCF8574A I2C-Bus dengan Arduino Uno.

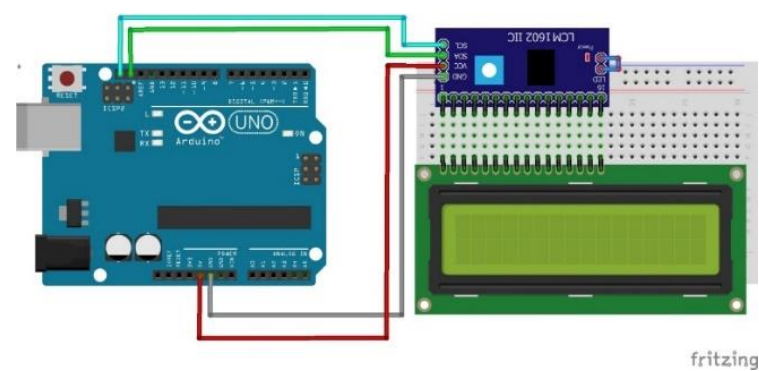

Gambar 6. Koneksi line komunikasi PCF8574A I2C-Bus dengan Arduino Uno

\section{Perancangan Rangkaian Arduino Uno to soil moisture sensor $Y L-69$}

Oil moisture sensor YL 69 merupakan sensor yang digunakan pada rancang bangun alat ukur kelembaban tanah berbasis Arduino Uno ini. Untuk sumber tegangan 5V soil moisture sensor YL 69 diambil pararel dari sumber tegangan dari VDD LCD dikarenakan slot tegangan $5 \mathrm{~V}$ pada board Arduino Uno hanya 1 dan sudah digunakan untuk menyuplai LCD. Dapat dilihat pada Gambar 7 line diagram Koneksi line soil moisture sensor YL 69 dengan Arduino Uno.

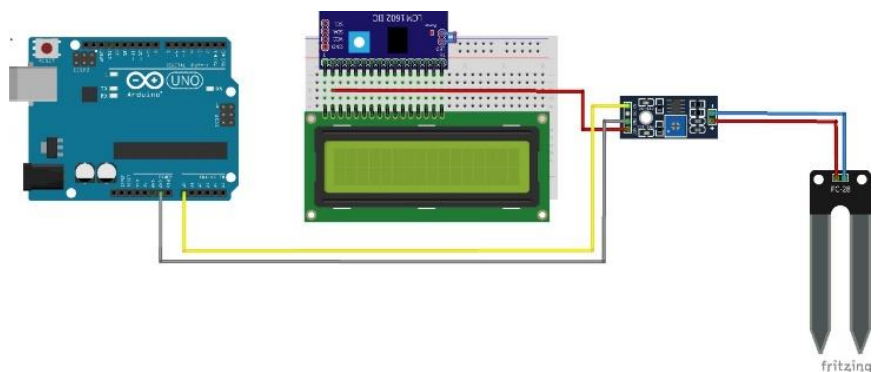

Gambar 7. Koneksi line soil moisture sensor YL 69 dengan Arduino Uno

\section{E. Perancangan Box/wadah}

Perancangan box / wadah menggunakan apliaksi Autodesk Fusion yang memudahkan dalam hal desain box / wadah. Box / wadah ini untuk menempatkan seluruh komponen dari rancang bangun alat ukur kelembaban tanah berbasis Arduino Uno. Wadah terbuat dari bahan plastik akrilik dengan ketebalan $2 \mathrm{~mm}$ putih bening / transparan. Dapat dilihat pada Gambar 8 bentuk Desain box / wadah 3 dimensi.

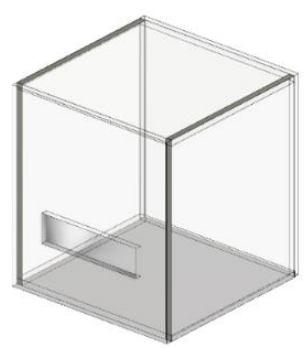

Gambar 8. Desain box / wadah 3 dimensi

\section{F. Perangkat Lunak}

Penggunaan prangkat lunak dalam rancang bangun alat ukur kelembaban tanah berbasis Arduino Uno sangatlah diperlukan, dari segi pemrograman, perancangan dan penyusunan. Aplikasi yang digunakan untuk pemrograman Arduino Uno adalah Arduino IDE kemudian aplikasi yang digunakan untuk menggambar rangkaian menggunakan Fritzing dan untuk menggambar box / wadah alat ukur kelembaban tanah berbasis Arduino Uno menggunakan aplikasi Autodesk Fusion.

\section{G. Diagram Alir}

Diagram alir utama pemrograman Arduino Uno dapat dilihat pada Gambar 9 di bawah ini :

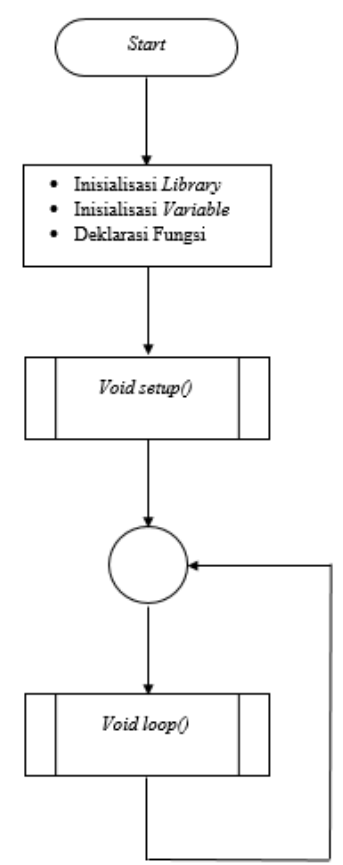

Gambar 9. Diagram alir utama 
Fungsi yang ada di dalam void setup() hanya akan dieksekusi satu kali saat sistem pertama kali dijalankan. dapat dilihat pada Gambar 10 di bawah ini :

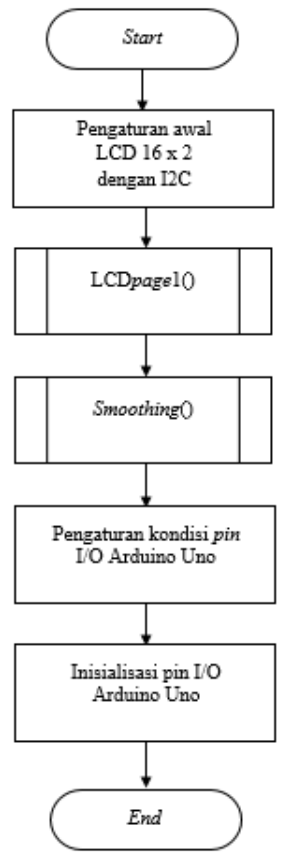

Gambar 10. Diagram alir void setup

Fungsi dari void loop() adalah fungsi yang akan dijalakan secara berulang - ulang. dapat dilihat pada Gambar 11 di bawah ini :

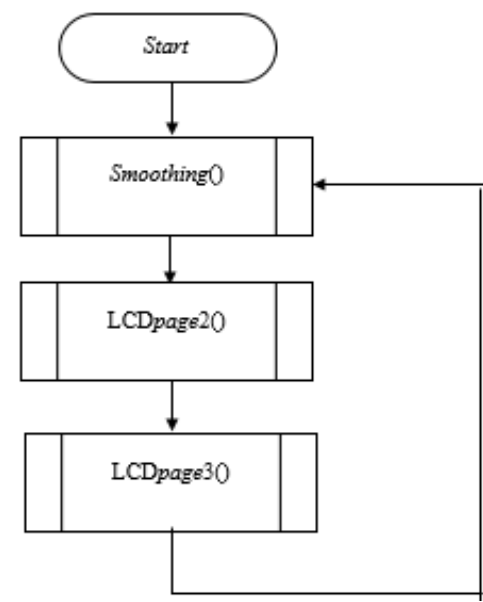

Gambar 11. Diagram alir void setup

\section{IV.HASIL DAN PEMBAHASAN}

\section{A. Tahap I}

Tahap I, yaitu mencari tahanan dari elektroda soil moisture sensor jenis YL - 69 dan membuktikan soil moisture sensor jenis YL - 69 menerapkan prinsip Ohmic atau sifat kelistrikan suatu benda yang mengikuti hukum Ohm.

Pada tahap I ini, pertama yang dilakukan yaitu, mencari tahanan 2 kabel penghantar pada input soil moisture sensor YL 69. Kabel penghantar yang digunakan adalah jenis kabel Dupont. Dengan tujuan menentukan nilai tahanan kabel

Submitted: 30/01/2020; Revised: 30/01/2020;

penghantar, agar dapat menentukan tahanan langsung dari probe dengan rumus :

Tahanan probe = Tahanan keseluruhan - Tahanan penghantar

Tahanan 2 kabel penghantar sebagai berikut :

1. Penghantar ( kuning ) $=0,57 \mathrm{Ohm}$

2. Penghantar (jingga $)=$

$\underline{0,8 \mathrm{Ohm}}$

Jadi, jumlah 2 tahanan kabel penghantar sebesar $0,8 \mathrm{Ohm}$.

Kedua, mencari tahanan probe dengan bantuan alat constant current \& multimeter. Probe soil moisture sensor YL 69 dihubung singkat dengan 2 posisi pada bagian $1 \& 7$ probe. dapat dilihat pada Gambar 12 di bawah ini.

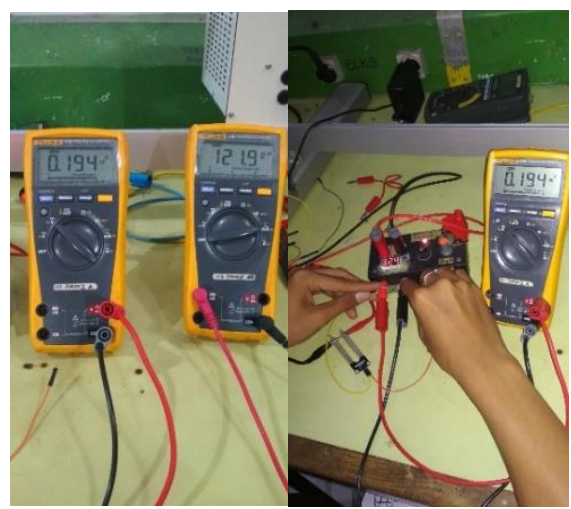

Gambar 12. Hubung singkat bagian 1 probe.

Ketiga, mencari tahanan probe dengan bantuan alat constant current \& multimeter. Probe soil moisture sensor YL 69 dihubung singkat pada posisi bagian 7 probe. dapat dilihat pada Gambar 13 di bawah ini.

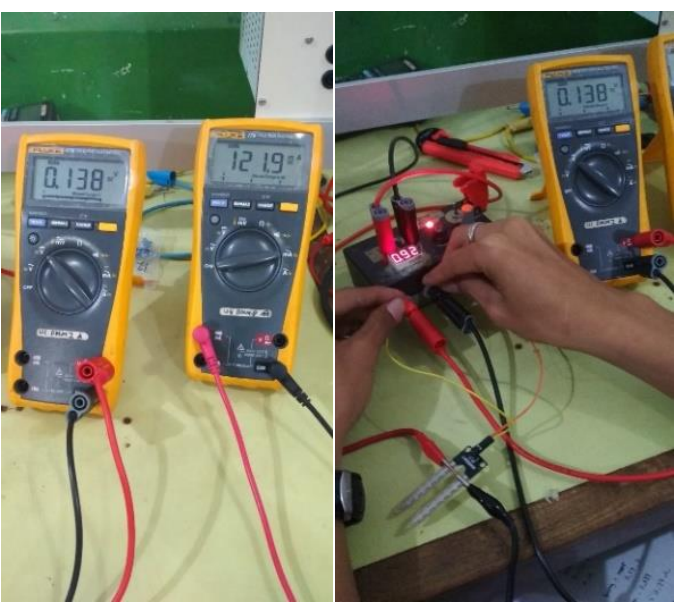

Gambar 13. Hubung singkat bagian 7 probe

Simpulan pada tahap I ini yaitu, dapat membuktikan bahwa probe soil moisture sensor YL 69 memiliki karakteristik berdasarkan hukum Ohm (ohmic). 


\section{B. Tahap II}

Tahap II, pengujian tingkat tahanan dan arus pada soil moisture sensor jenis YL - 69, dengan tegangan refrensi 3,3 V dan $5 \mathrm{~V}$. Pada tahap II, pengujian menggunakan tanah sebagai media penelitian, air (Aqua) sebagai media kelembaban buatan dan Soil Tester Takamura model DM-05 sebagai media acuan atau pembanding. Berikut plot data yang di peroleh setiap percobaan pada Tahap II ini yang di tunjukan pada Gambar 14, Gambar 15, dana Gambar 16.

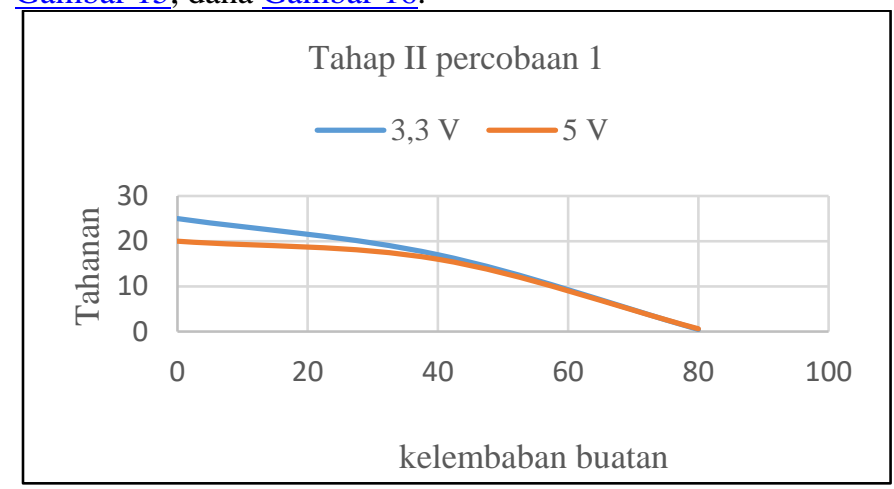

Gambar 14. Grafik tahap II percobaan 1

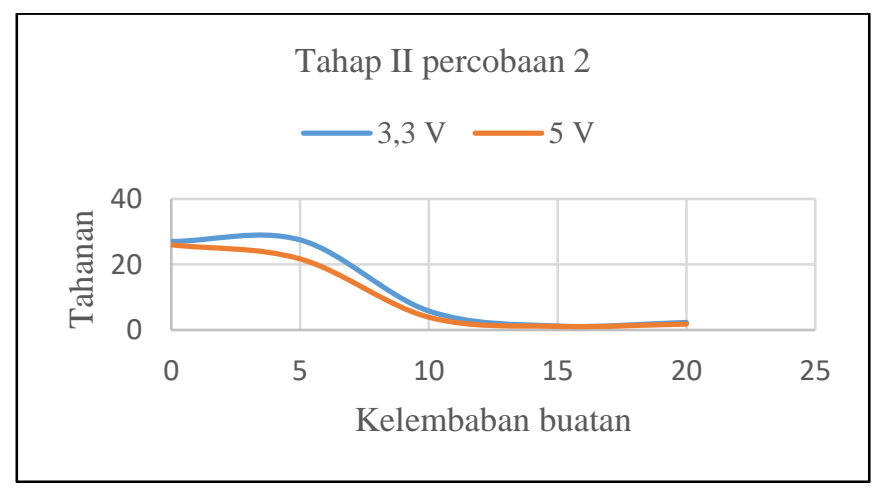

Gambar 15. Grafik tahap II percobaan 2

Tahap II percobaan 3

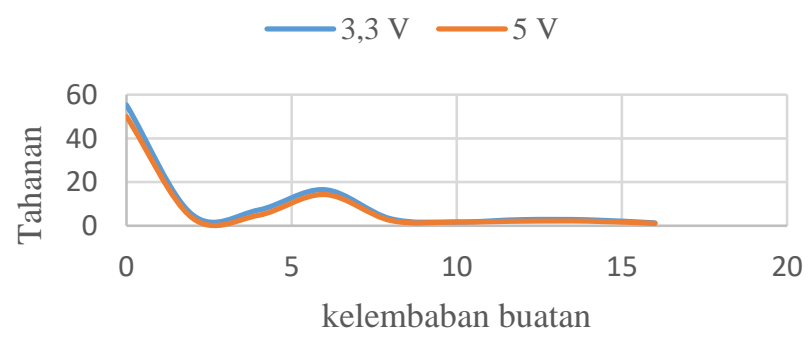

Gambar 16. Grafik tahap II percobaan 3

Berdasarkan Gambar 14 , Gambar 15, dan Gambar 16 dapat terliht bahwa terdapat korelasi antara kelembaban dengan nilai tahanan sensor YL 69. Berlaku sama tegangan ADC 3,3 V dan $5 \mathrm{~V}$.

Berdasarkan dari beberapa percobaan pada tahap II ini dapat disimpulkan yaitu, $5 \mathrm{~V}$ dipilih sebagai sumber tegangan pada soil moisture dikarenakan tegangan $5 \mathrm{~V}$ memiliki rentang resolusi per bit yang panjang dibandingkan dari tegangan 3,3 V.

\section{Tahap III}

Tahap III, mencari fungsi persamaan dari data yang telah didapat pada pengujian tahap dua, dan membandingkan hasil data yang didapatkan dari soil moisture sensor jenis YL - 69 dengan Soil Tester Takamura model DM-05 menggunakan grafik perbandingan-perbandingan sehingga mendapatkan fungsi/persamaan akhir yang siap diterapkan ke dalam program Arduino Uno. Pada tahap III ini sama seperti pada tahap II ada beberapa langkah percobaan yang dilakukan.

Percobaan pertama, dilakukan perbandingan dan pengambilan data yaitu kelembaban buatan (ml), ADC, VCC, VA0, Soil Tester (\%), Range YL 69 (\%). Dapat dilihat pada Tabel 1 dibawah ini.

TABEL 1

DATA TAHAP III PERCOBAAN PERTAMA

\begin{tabular}{|c|c|c|c|c|c|c|}
\hline percobaan & $\begin{array}{c}\text { kelembaban } \\
\text { buatan (ml) }\end{array}$ & ADC & vcc & V A0 & $\begin{array}{c}\text { Soil } \\
\text { Tester } \\
\%\end{array}$ & $\begin{array}{c}\% \\
\text { range } \\
\text { YL } \\
69\end{array}$ \\
\hline 1 & 0 & 838 & 4,828 & 4,070 & 30 & 18 \\
\hline 2 & 2 & 747 & 4,848 & 3,670 & 46 & 27 \\
\hline 3 & 4 & 460 & 4,818 & 2,210 & 66 & 56 \\
\hline 4 & 6 & 424 & 4,853 & 2,038 & 79 & 60 \\
\hline 5 & 8 & 356 & 4,806 & 1,670 & 100 & 66 \\
\hline 6 & 10 & 347 & 4,803 & 1,630 & 100 & 67 \\
\hline
\end{tabular}

Percobaan kedua, dilakukan perbandingan dan pengambilan data yang sama dengan percobaan pertama yaitu kelembaban buatan (ml), ADC, VCC, VA0, Soil Tester (\%), Range YL 69 (\%), akan tetapi dengan data yang lebih detail dan lebih banyak. Dapat dilihat pada Tabel 2 di bawah ini.

TABEL 2

DATA TAHAP III PERCOBAAN KEDUA

\begin{tabular}{|c|c|c|c|c|c|c|}
\hline $\begin{array}{c}\text { Percoba } \\
\text { an }\end{array}$ & $\begin{array}{c}\text { kelembab } \\
\text { an buatan } \\
(\mathrm{ml})\end{array}$ & ADC & vcc & V A0 & $\begin{array}{c}\text { Soil } \\
\text { Tester } \\
\%\end{array}$ & $\begin{array}{c}\% \text { range } \\
\text { YL 69 }\end{array}$ \\
\hline 1 & 0 & 894 & 4,851 & 4,320 & 30 & 13 \\
\hline 2 & 2 & 890 & 4,853 & 4,217 & 38 & 13 \\
\hline 3 & 4 & 848 & 4,852 & 4,068 & 40 & 17 \\
\hline 4 & 6 & 664 & 4,840 & 3,168 & 50 & 35 \\
\hline 5 & 8 & 630 & 4,833 & 2,995 & 52 & 39 \\
\hline 6 & 10 & 605 & 4,820 & 2,830 & 70 & 42 \\
\hline 7 & 12 & 515 & 4,836 & 2,487 & 90 & 50 \\
\hline 8 & 14 & 500 & 4,844 & 2,379 & 100 & 52 \\
\hline 9 & 16 & 438 & 4,820 & 2,056 & 100 & 58 \\
\hline 10 & 18 & 366 & 4,860 & 1,726 & 100 & 65 \\
\hline 11 & 20 & 359 & 4,827 & 1,566 & 100 & 66 \\
\hline
\end{tabular}

Percobaan ketiga, dilakukan perbandingan dan pengambilan data yang sama dengan percobaan kedua yaitu kelembaban buatan (ml), ADC, VCC, VA0, Soil Tester (\%), Range YL 69 (\%), akan tetapi pada percobaan ketiga ini yang membedakan dari percobaan kedua yaitu pada perlakuan kelembaban buatan. Pada percobaan ketiga ini kelembaban buatan lebih merata keseluruh bagian tanah dan data yang diambil lebih akurat dari pada percobaan kedua. Dapat dilihat pada Tabel 3 dibawah ini. 
TABEL 3

DATA TAHAP III PERCOBAAN KETIGA

\begin{tabular}{|c|c|c|c|c|c|c|}
\hline percobaan & $\begin{array}{c}\text { kelembaba } \\
\mathrm{n} \text { buatan } \\
(\mathrm{ml})\end{array}$ & ADC & vcc & V A0 & $\begin{array}{c}\text { Soil } \\
\text { Teste } \\
\text { \% }\end{array}$ & $\begin{array}{c}\% \\
\text { range } \\
\text { YL } \\
69\end{array}$ \\
\hline 1 & 0 & 870 & 4,817 & 4,190 & 40 & 15 \\
\hline 2 & 2 & 869 & 4,870 & 4,156 & 42 & 15 \\
\hline 3 & 4 & 805 & 4,849 & 3,884 & 50 & 21 \\
\hline 4 & 6 & 664 & 4,823 & 3,263 & 58 & 36 \\
\hline 5 & 8 & 560 & 4,846 & 2,602 & 66 & 46 \\
\hline 6 & 10 & 535 & 4,823 & 2,495 & 70 & 48 \\
\hline 7 & 12 & 492 & 4,812 & 2,340 & 89 & 53 \\
\hline 8 & 14 & 457 & 4,830 & 2,067 & 100 & 56 \\
\hline 9 & 16 & 389 & 4,836 & 1,793 & 100 & 63 \\
\hline 10 & 18 & 365 & 4,823 & 1,737 & 100 & 65 \\
\hline 11 & 20 & 358 & 4,833 & 1,702 & 100 & 66 \\
\hline
\end{tabular}

Dapat disimpulkan dari 3 percobaan di atas, pada setiap tabel data ada perlakuan berbeda terhadap kelembaban buatan yaitu pada langkah pertama, kelembaban buatan hanya terfokus pada titik kelembaban tertentu atau tidak menyeluruh (tanah tidak di aduk rata). Pada langkah kedua, kelembaban buatan terfokus pada titik keseluruhan tanah sehingga kelembaban buatan merata (tanah diaduk rata). Pada langkah ketiga, dengan perlakuan yang sama dengan langkah kedua, yang membedakan pada langkah ketiga ini adalah pengambilan data yang lebih lama dari pada langkah kedua disebabkan menunggu hasil data yang stabil dan pasti.

Jadi, data percobaan yang lebih akurat yaitu percobaan kedua dan ketiga, dari data percobaan kedua dan ketiga, data ADC dan hasil pengukuran soil tester yang akan dibuatkan fungsi agar bisa diterapkan pada coding program. Berikut tabel data gabungan ADC dan hasil pengukuran soil tester dari percobaan kedua dan ketiga. Dapat dilihat pada Tabel 4 di bawah ini.

TABEL 4

DATA GABUNGAN PERCOBAAN 2 DAN 3

\begin{tabular}{|c|c|}
\hline ADC & Soil Tester \% \\
\hline 894 & 30 \\
\hline 890 & 38 \\
\hline 870 & 40 \\
\hline 869 & 40 \\
\hline 848 & 42 \\
\hline 805 & 50 \\
\hline 664 & 50 \\
\hline 664 & 52 \\
\hline 630 & 58 \\
\hline 605 & 66 \\
\hline 560 & 70 \\
\hline 535 & 70 \\
\hline 515 & 89 \\
\hline 500 & 90 \\
\hline 492 & 100 \\
\hline 457 & 100 \\
\hline 438 & 100 \\
\hline 389 & 100 \\
\hline
\end{tabular}

Pada Tabel 4 di atas didapatkan persamaan dan gambar grafik. Dapat dilihat pada Gambar 17 grafik data gabungan percobaan 2 dan 3 di bawah ini.

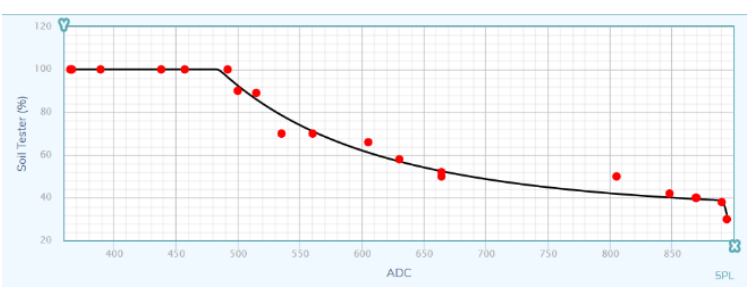

Gambar 17. Grafik data gabungan percobaan 2 dan 3

Persamaan :

$\mathrm{y}=32,21216+(100-32,21216) /\left(1+(\mathrm{x} / 484,3834)^{\wedge} 1158,417\right)$ $\wedge 0,003309129$

Dari persamaan di atas telah diuji coba penerapannya pada coding pemrograman, hanya saja terdapat kendala, dalam kinerja pengukuran kelembaban tanah yang tidak sesuai dan akurat, dikarenakan data grafik di atas dengan fungsi power akan menyulitkan perhitungan pada Arduino Uno sehingga pengukuran dari hasil perhitungan tidak sesuai. Maka data gabungan percobaan 2 dan 3 akan dipangkas dengan tujuan mengambil data yang memiliki kenaikan yang linear. Berikut tabel data ADC dan hasil pengukuran soil tester yang telah dipangkas dari percobaan 2 dan 3. Dapat dilihat pada Tabel 5 di bawah ini.

TABEL 5

DATA GABUNGAN PERCOBAAN 2 DAN 3 LINEAR

\begin{tabular}{|c|c|}
\hline ADC & Soil Tester \% \\
\hline 894 & 30 \\
\hline 890 & 38 \\
\hline 870 & 40 \\
\hline 869 & 40 \\
\hline 848 & 42 \\
\hline 805 & 50 \\
\hline 664 & 50 \\
\hline 664 & 52 \\
\hline 630 & 58 \\
\hline 605 & 66 \\
\hline 560 & 70 \\
\hline 535 & 70 \\
\hline 515 & 89 \\
\hline 500 & 90 \\
\hline 492 & 100 \\
\hline
\end{tabular}

Pada Tabel 5 di atas didapatkan persamaan dan gambar grafik. Dapat dilihat pada Gambar 18 grafik data gabungan percobaan 2 dan 3 linear di bawah ini.

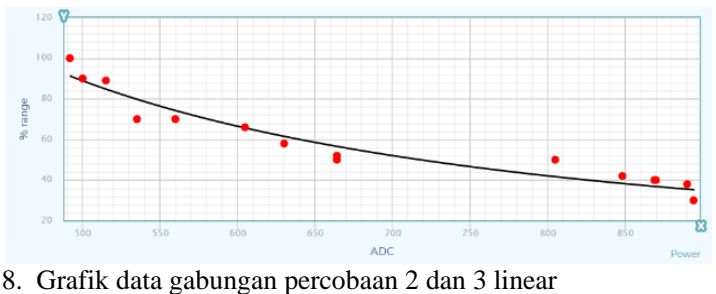

Gambar 18. Grafik data gabungan percobaan 2 dan 3 linear

Submitted: 30/01/2020; Revised: 30/01/2020; 
Persamaan :

$y=1741722 * x^{\wedge}-1,590429$

Dari persamaan di atas terlihat lebih simple dibandingkan dari persamaan sebelumnya, begitu pula pada grafik di atas lebih terlihat linear. Persamaan yang telah didapat telah diuji coba pada coding pemrograman dan hasil dari pengukuran serta akurasi yang sesuai dan mendekati dari pengukuran alat khusus soil tester Takamura model DM 5.

Berdasarkan dari beberapa percobaan pada tahap III ini dapat disimpulkan yaitu formula/fungsi perhitungan yang akan diterapkan pada coding pemrograman Arduino Uno yaitu :

$y=1741722 * x^{\wedge}-1,590429$

\section{Pengkategorian Kondisi Tanah}

Dari beberapa percobaan yang telah dilakukan dan melalui beberapa tahap dapat ditentukan range nilai ukur dari alat ini, yang ditunjukan pada Tabel 6 di bawah ini.

TABEL 6

PENGKATEGORIAN KONDISI TANAH

\begin{tabular}{|c|c|c|}
\hline $\mathrm{ADC}$ & range $\%$ & kondisi (potensio) \\
\hline 894 & 28,44 & sangat kering \\
\hline 894 & 29,97 & sangat kering \\
\hline 894 & 30,45 & sangat kering \\
\hline 894 & 31,31 & sangat kering \\
\hline 894 & 32,76 & sangat kering \\
\hline 894 & 33,44 & sangat kering \\
\hline 894 & 34,20 & sangat kering \\
\hline 890 & 35,50 & kering \\
\hline 879 & 36,21 & kering \\
\hline 861 & 37,42 & kering \\
\hline 847 & 38,41 & kering \\
\hline 837 & 39,14 & kering \\
\hline 821 & 40,36 & kering \\
\hline 805 & 41,64 & kering \\
\hline 795 & 42,48 & kering \\
\hline 784 & 43,43 & kering \\
\hline 774 & 44,32 & kering \\
\hline 761 & 45,53 & kering \\
\hline 755 & 46,11 & kering \\
\hline 745 & 47,10 & kering \\
\hline 733 & 48,33 & kering \\
\hline 723 & 49,40 & kering \\
\hline 715 & 50,28 & normal \\
\hline 706 & 51,30 & normal \\
\hline 697 & 52,36 & normal \\
\hline 690 & 53,21 & normal \\
\hline 680 & 54,64 & normal \\
\hline
\end{tabular}

\begin{tabular}{|c|c|c|}
\hline 672 & 55,49 & normal \\
\hline 663 & 56,70 & normal \\
\hline 656 & 57,66 & normal \\
\hline 648 & 58,80 & normal \\
\hline 640 & 59,97 & normal \\
\hline 635 & 60,72 & normal \\
\hline 632 & 61,18 & normal \\
\hline 626 & 62,12 & normal \\
\hline 620 & 63,08 & normal \\
\hline 612 & 64,39 & normal \\
\hline 606 & 65,41 & normal \\
\hline 599 & 66,63 & basah \\
\hline 594 & 67,53 & basah \\
\hline 588 & 68,62 & basah \\
\hline 585 & 69,19 & basah \\
\hline 580 & 70,14 & basah \\
\hline 571 & 71,90 & basah \\
\hline 569 & 72,31 & basah \\
\hline 563 & 73,53 & basah \\
\hline 557 & 74,80 & basah \\
\hline 553 & 75,66 & basah \\
\hline 548 & 76,76 & basah \\
\hline 545 & 77,43 & basah \\
\hline 541 & 78,35 & basah \\
\hline 537 & 79,28 & basah \\
\hline 531 & 80,71 & basah \\
\hline 526 & 81,93 & basah \\
\hline 523 & 82,68 & basah \\
\hline 520 & 83,44 & basah \\
\hline 516 & 84,47 & basah \\
\hline 511 & 85,79 & basah \\
\hline 507 & 86,87 & basah \\
\hline 505 & 87,42 & basah \\
\hline 500 & 88,81 & basah \\
\hline 497 & 89,66 & basah \\
\hline 494 & 90,53 & sangat basah \\
\hline 492 & 91,41 & sangat basah \\
\hline 492 & 92,91 & sangat basah \\
\hline 492 & 93,22 & sangat basah \\
\hline 492 & 94,14 & sangat basah \\
\hline 492 & 95,72 & sangat basah \\
\hline 492 & 96,04 & sangat basah \\
\hline 492 & 97,66 & sangat basah \\
\hline 492 & 98,33 & sangat basah \\
\hline 492 & 99,67 & sangat basah \\
\hline 492 & 100,02 & sangat basah \\
\hline
\end{tabular}

Submitted: 30/01/2020; Revised: 30/01/2020;

Accepted: 30/06/2020; Online first: 30/06/2020

http://dx.doi.org/10.46964/poligrid.v1i1.215 
Pada Tabel 6 di atas telah dirincikan ADC, persentase kelembaban dan kategori kondisi tanah, dapat dilihat pada gambar - gambar di bawah ini yang merupakan salah satu contoh pengambilan data lapangan pada tanaman mangga dan hasil dari pengukurannya. Dapat dilihat pada Gambar 19, Gambar 20 dan Gambar 21.

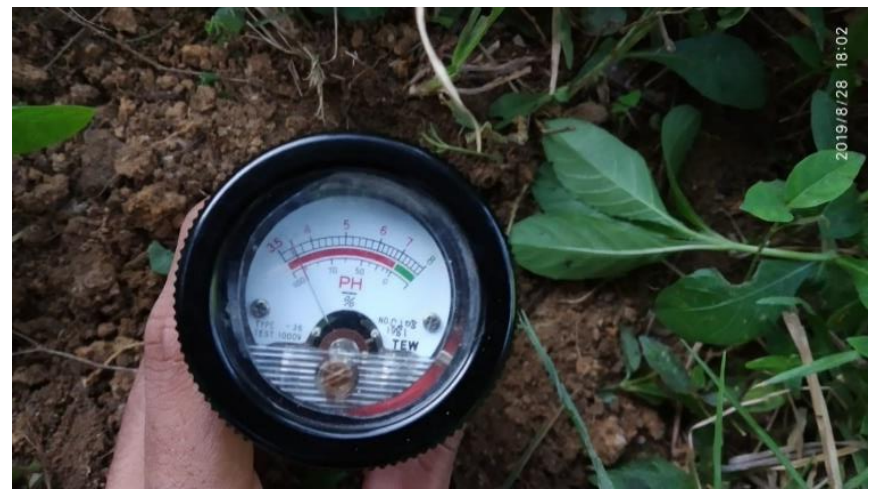

Gambar 19. Hasil pengukuran dengan soil tester

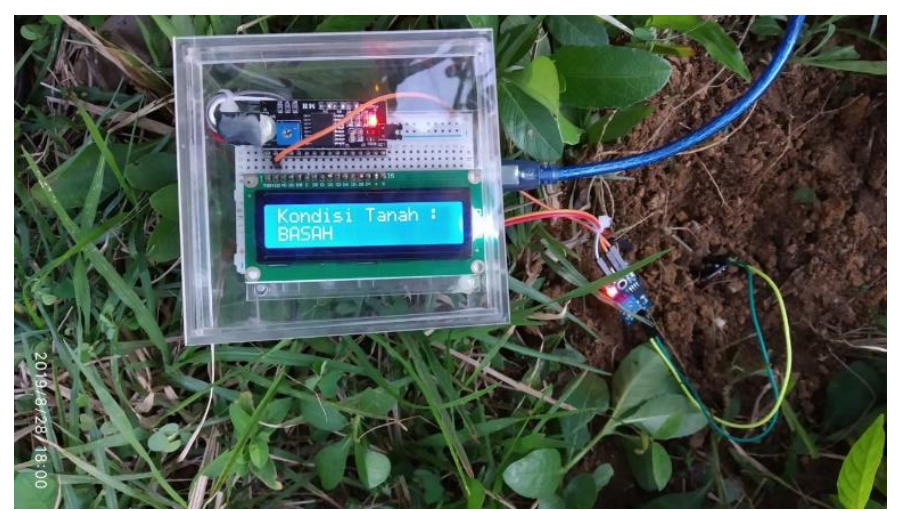

Gambar 20. Hasil pengukuran kelembaban berbasis Arduino Uno

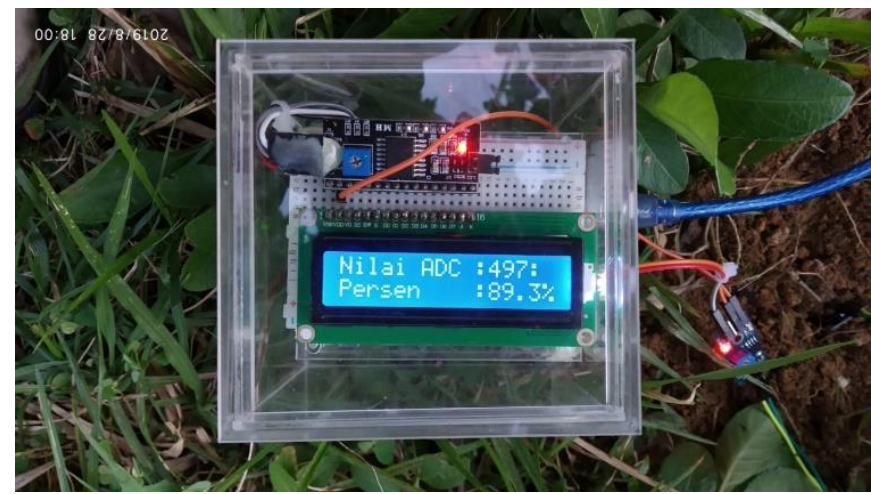

Gambar 21. Kondisi tanah objek pengujian

Dari Gambar 19, 20, dan 21 di atas telah dilakukan pengukuran langsung pada objek yaitu tanaman mangga yang terletak di Jurusan Teknik Elektro Politeknik Negeri Samarinda. Berdasarkan hasil pengukuran didapatkan data sebagai berikut. Dapat dilihat pada Tabel 7 di bawah.
TABEL 7

PENGUKURAN KELEMBABAN POHON MANGGA

\begin{tabular}{|c|c|c|c|c|}
\hline Objek & $\begin{array}{c}\text { Soil } \\
\text { tester }\end{array}$ & $\begin{array}{c}\text { Pengukuran } \\
\text { berbasis } \\
\text { Arduino Uno }\end{array}$ & $\begin{array}{c}\text { Selisih } \\
\text { pengukuran }\end{array}$ & Konsisi \\
\hline $\begin{array}{c}\text { Pohon } \\
\text { mangga }\end{array}$ & $91 \%$ & $89,3 \%$ & $1,7 \%$ & Basah \\
\hline
\end{tabular}

\section{KESIMPULAN}

Setelah melakukan rancang bangun alat ukur kelembaban tanah berbasis Arduino Uno, dapat mengambil beberapa simpulan sebagai berikut :

1. Sistem pemantau kelembaban tanah berbasis Arduino Uno dengan sensor YL 69 memiliki keakurasian pengukuran dengan selisih kurang lebih 1,7\% dari alat pembanding berupa soil tester Takamura DM 5.

2. Sistem pemantauan kelembaban tanah berbasis Arduino Uno ini diatur untuk memberikan informasi kondisi kelembaban tanah dalam 5 kategori pengukuran yaitu (sangat kering, kering, normal, basah, sangat basah).

3. Berdasarkan hasil pengujian, Arduino Uno tidak mampu melakukan perhitungan matematis untuk fungsi persamaan dalam bentuk pemangkatan (power) yang kompleks dan hanya bisa menghitung fungsi persamaan dalam bentuk linear.

4. Sistem alat yang dihasilkan dari rancang bangun ini tidak dapat menggantikan alat ukur sejenis soil tester Takamura DM 5 karena kemampuan yang tidak sebanding.

\section{REFERENSI}

[1] S. A.. Nugroho, "Analisis kelembaban tanah permukaan melalui citra Landsat 7 ETM+ di wilayah dataran Kabupaten Purworejo”, Skripsi, Universitas Muhammadiyah Surakarta, Surakarta, 2011.

[2] U. Hasanah, S. Nurjannah, R. Umami, N. Afifah, V. A. Papuja and A. Khusna, Petunjuk Praktikum Ekologi Tumbuhan Pengukuran Suhu, Kelembaban Udara, Tanah dan pH Tanah Serta Kadar Air dan C Organik Tanah, Laboratorium Biologi, Universitas Muhammadiyah Malang, Malang, 2014.

[3] B. Pranata, Rancang Bangun Open Loop Boost Converter dengan pengendali Arduino Uno, Samarinda, 2016.

[4] S. Suhaeb, Y. A. Djawad, H. Jaya, Ridwansyah, Sbran, A. Risal, Buku Ajar Mikrokontroler dan Interface, Universitas Negeri Makassar, Makassar, 2017.

[5] D. Rahmawati, F. Herawati, G. Saputra and H. , "Karakteristik Sensor Kelembaban Tanah (YL-69) untuk Otomatisasi Penyiraman Tanaman Berbasis Arduino Uno", Prosiding SKF 2017, Bandung, 2017.

[6] F. Surya, I2C Protokol, Ubinus, 2007.

[7] Takemura dm 5/dm5/dm-5 soil pH \& moisture mater, Accessed July 2019, Tokopedia, [Online]. Available: http://www.pricearea.com/ jump_deeplink? m=tokopedia.com\&listing_id=272396990. 